\title{
Canadian university research libraries during the early days of the COVID-19 pandemic
}

\author{
Les bibliothèques \\ universitaires du \\ Canada tout au début \\ de la pandémie \\ COVID-19
}

\section{Channarong Intahchomphoo}

University of Ottawa Library

\section{Michelle Brown \\ University of Ottawa Library}

\begin{abstract}
This paper documents the services and changes that library staff at a group of 15 Canadian university research libraries highlighted on their main pandemic pages and social media accounts during the early days of the coronavirus (COVID-19) pandemic. Findings suggest that libraries in the samples adopted the following services and changes: closing the physical libraries; suspending all physical collection services and in-person events; continuing to provide virtual reference services; promoting access and usage of electronic collections; suspending late fees and renewing checked-out items with a new due date; and advising users to wait before returning borrowed items. Notably, all libraries in this study were operating as full-scale digital libraries. This study will provide lessons learned to other libraries around the world to help in reviewing their own operational policies for coping with the current COVID-19 pandemic and for future global public health crises.
\end{abstract}

Keywords: services and changes, university libraries, Canada, COVID-19 pandemic

Résumé : Cet article documente les changements signalés par les membres du personnel de 15 bibliothèques universitaires au cours des premiers jours de la pandémie du COVID-19. L'étude examine l'ensemble des communications sur les pages web et aux comptes de médias sociaux portant sur les changements et services à la bibliothèque liée à la COVID-19. Les résultats suggèrent que les bibliothèques dans l'échantillon ont adopté les services et les changements qui suit : une fermeture des bibliothèques physiques; la suspension de tous les services de collecte physique et les événements en personne; la continuation de fourniture de services de référence virtuels; la promotion de l'accès et de l'utilisation des collections électroniques; la suspension des frais de retard et le renouvèlement de documents à une date

(C) The Authors 2021. Canadian Journal of Information and Library Science 
plus éloigner; et servir la clientèle en avisant que les utilisateurs attendant avant de retourner leur document empruntés. Notamment, toutes les bibliothèques de cette étude fonctionnent à pleine échelle en tant que bibliothèques numériques. Cette étude vise à aider les autres bibliothèques au monde entier qui font face à la pandémie actuelle du COVID-19, en transmettant les leçons tirées de ces 15 bibliothèques. Elle pourrait également servir à informer les bibliothèques qui souhaitent développer leurs politiques opérationnelles en contexte de futures crises en santé publique.

Mots clés : services et changements, bibliothèques universitaires, Canada, pandémie de COVID-19

\section{Introduction}

The COVID-19 pandemic is an unprecedented crisis that has affected every country in various ways. The virus has taken many lives and it has also created many political, economic, and social issues. Public health officials have ordered physical distancing rules and home isolation to flatten the curve of the new infection rate, and to avoid overwhelming health care systems while waiting for a vaccine. COVID-19 has disrupted the operation of public and private organizations worldwide including university libraries. Many universities, including their libraries, have temporarily closed and all in-person classes have moved online.

This paper aims to document the services and changes that library personnel at a group of 15 Canadian university research libraries highlighted on their main pandemic pages and social media accounts during the early days of the COVID-19 pandemic. According to the data from the Government of Canada, as of June 3, 2020, the number of total cases of COVID-19 in Canada was 93,085 and within that number there are 7,498 deaths (Government of Canada 2020). The authors hope this study will provide the lessons learned by these Canadian libraries for others around the world to assist in reviewing their own operational policies for coping with the current COVID-19 pandemic and for future global public health crises.

Our search in the Library, Information Science and Technology Abstracts (LISTA) database, which contains more than 610 journals dating back to 1960, shows that there are two distinct groups in the literature on libraries' strategic planning for crisis management and response. The first group discusses the strategies for financial crises and their impact on library operations. Pascarelli (1990) discusses coping strategies of libraries when facing a financial crisis with serial price increases. This poses challenges for collection development. Fitchett et al. (2011) mention that academic law libraries, in response to the 2008-2009 global financial crisis, had to seek innovative strategies and plan to operate with reduced resources, which included changing organizational structures, library space, and collection management. Ayris (2012) discusses the development of European library services during the economic downturn and recommends increasing collaborative projects between different libraries, such as having a joint procurement strategy and a collaborative cataloguing strategy. Copyright reform and the open access movement were also suggested as coping strategies in difficult financial times. 
The second distinct group in the literature is about the roles and strategies used by libraries in political and public health crises. Beetseh, Tion, and Terwase (2018) explain the roles and strategies used by librarians in Nigeria in combatting long-term food crises and violence among different groups of farmers. Librarians in Nigeria started to disseminate early warning information through both online and offline channels to alert the public about a potential conflict. Their roles in community information dissemination also put pressure on the government to quickly act on the escalating crisis. In this unique case, librarians become peace makers and first responders for community safety. Lastly, Kanyengo (2010) explains how the University of Zambia Medical Library fought against the HIV/AIDS crisis in Zambia by offering information literacy skills programs and developing collections that were accessible for the public and researchers. They included information and materials related to disease prevention, treatment, and medical and social supports for patients. According to the literature in the database at the time this research project was conducted, there was no academic literature documenting the strategies and service changes used by information organizations including libraries, archives, or museums for coping with the COVID-19 pandemic.

\section{Methodology}

The "U15" is a group of research-intensive universities in Canada (Group of Canadian Research Universities 2020). Their main research activities are financially supported by the government, with some portions coming from the private sector. Table 1 below shows the URLs of the U15 library homepages and their COVID-19 update webpages. The first phase of the data collection was classified into 3 categories: the revised library services, strategies to support research activities, and strategies to support teaching and learning. Data in each category were clustered based on their thematic similarity (Braun and Clarke 2006). The second data collection phase was done by reviewing the social media accounts of the selected libraries. We searched for posts related to their service and operations during the COVID-19 crisis (see Table 2) and used the social media data as examples of how libraries engaged with users. Once both phases of data collection were complete, data from the COVID-19 updates webpages and social media posts were cross tabulated between the samples.

The first stage of data collection for the library's COVID-19 update webpages took place between April 1, 2020 and April 18, 2020. The second stage of data collection on the libraries' social media accounts was conducted from April 27, 2020 to May 29, 2020. We looked at all posts made between the beginning of March 2020 to May 29,2020 . In cases where the COVID-19 update webpages contained multiple subpages addressing specific concerns and changes in the library services, we reviewed those subpages as well. However, since the COVID-19 pandemic is an unfolding event impacting library operations, new information was constantly being revised or added to those COVID-19 update webpages. Therefore, some data are not reported in this paper due to the timeframe of our data collection. The authors have put forward this concern as a limitation of this study. Moreover, the authors acknowledge that decisions made by library staff about what not to include on their pandemic webpages may have been influenced by avoiding duplicating statements from main university administrative 
offices. Therefore, findings reported in the following section only describe what library staff chose to put on their main pandemic webpages and social media accounts.

\begin{tabular}{|c|c|c|c|}
\hline \multicolumn{2}{|c|}{$\begin{array}{c}\text { Canadian University } \\
\text { Research Libraries } \\
\text { (U15) }\end{array}$} & \multirow{2}{*}{$\begin{array}{l}\text { Library Homepage } \\
\text { https://www.library. } \\
\text { ualberta.ca }\end{array}$} & \multirow{2}{*}{$\begin{array}{l}\text { Library's COVID-19 } \\
\text { Update Webpage } \\
\text { https://www.library.ualberta } \\
\text {.ca/COVID-19 }\end{array}$} \\
\hline 1 & $\begin{array}{l}\text { University of Alberta } \\
\text { Library (Alberta) }\end{array}$ & & \\
\hline 2 & $\begin{array}{l}\text { University of British } \\
\text { Columbia Library } \\
\text { (British Columbia) }\end{array}$ & $\begin{array}{l}\text { https://www.library.ubc. } \\
\text { ca }\end{array}$ & $\begin{array}{l}\text { https://services.library.ubc. } \\
\text { ca/covid-19-response/ }\end{array}$ \\
\hline 3 & $\begin{array}{l}\text { University of Calgary } \\
\text { Library (Calgary) }\end{array}$ & https://library.ucalgary.ca & $\begin{array}{l}\text { https://library.ucalgary.ca/ } \\
\text { guides/covid-19 }\end{array}$ \\
\hline 4 & $\begin{array}{l}\text { Dalhousie University } \\
\text { Libraries (Dalhousie) }\end{array}$ & https://libraries.dal.ca & $\begin{array}{l}\text { https://libraries.dal.ca/covid } \\
\text {-19-updates.html }\end{array}$ \\
\hline 5 & $\begin{array}{l}\text { Bibliothèque de } \\
\text { I'Université Laval } \\
\text { (Laval) }\end{array}$ & $\begin{array}{l}\text { https://www5.bibl.ulaval. } \\
\text { ca }\end{array}$ & $\begin{array}{l}\text { https://www5.bibl.ulaval.ca/ } \\
\text { mesures-de-la-bibliotheque- } \\
\text { covid19 }\end{array}$ \\
\hline 6 & $\begin{array}{l}\text { University of } \\
\text { Manitoba Libraries } \\
\text { (Manitoba) }\end{array}$ & $\begin{array}{l}\text { https://umanitoba.ca/ } \\
\text { libraries }\end{array}$ & $\begin{array}{l}\text { https://libguides.lib.umanito } \\
\text { ba.ca/covid-19-libraryaccess }\end{array}$ \\
\hline 7 & $\begin{array}{l}\text { McGill University } \\
\text { Library \& Archives } \\
\text { (McGill) }\end{array}$ & $\begin{array}{l}\text { https://www.mcgill.ca/ } \\
\text { library }\end{array}$ & $\begin{array}{l}\text { https://www.mcgill.ca/ } \\
\text { library/covid-19-latest }\end{array}$ \\
\hline 8 & $\begin{array}{l}\text { McMaster University } \\
\text { Library (McMaster) }\end{array}$ & $\begin{array}{l}\text { https://library.mcmaster. } \\
\text { ca }\end{array}$ & $\begin{array}{l}\text { https://library.mcmaster.ca/ } \\
\text { covid19 }\end{array}$ \\
\hline 9 & $\begin{array}{l}\text { Bibliothèques de } \\
\text { l'Université de } \\
\text { Montréal (Montréal) }\end{array}$ & https://bib.umontreal.ca & $\begin{array}{l}\text { https://bib.umontreal.ca/ } \\
\text { coronavirus }\end{array}$ \\
\hline 10 & $\begin{array}{l}\text { University of Ottawa } \\
\text { Library (Ottawa) }\end{array}$ & $\begin{array}{l}\text { https://biblio.uottawa.ca/ } \\
\text { en }\end{array}$ & $\begin{array}{l}\text { https://www.uottawa.ca/ } \\
\text { coronavirus/en }\end{array}$ \\
\hline 11 & $\begin{array}{l}\text { Queen's University } \\
\text { Library (Queen's) }\end{array}$ & https://library.queensu.ca & $\begin{array}{l}\text { https://library.queensu.ca/ } \\
\text { help-services/covid-19- } \\
\text { updates-library-services- } \\
\text { operations }\end{array}$ \\
\hline 12 & $\begin{array}{l}\text { University of } \\
\text { Saskatchewan Library } \\
\text { (Saskatchewan) }\end{array}$ & $\begin{array}{l}\text { https://library.usask.ca/ } \\
\text { index.php }\end{array}$ & $\begin{array}{l}\text { https://libguides.usask.ca/ } \\
\text { libraryupdates }\end{array}$ \\
\hline 13 & $\begin{array}{l}\text { University of Toronto } \\
\text { Libraries (Toronto) }\end{array}$ & $\begin{array}{l}\text { https://onesearch.library. } \\
\text { utoronto.ca }\end{array}$ & $\begin{array}{l}\text { https://onesearch.library. } \\
\text { utoronto.ca/news/covid-19- } \\
\text { updates-library-services- } \\
\text { and-operations }\end{array}$ \\
\hline
\end{tabular}




\begin{tabular}{|c|l|l|l|}
\hline 14 & $\begin{array}{l}\text { University of } \\
\text { Waterloo Library } \\
\text { (Waterloo) }\end{array}$ & $\begin{array}{l}\text { https://lib.uwaterloo.ca/ } \\
\text { web/index.php }\end{array}$ & $\begin{array}{l}\text { https://uwaterloo.ca/ } \\
\text { coronavirus/ }\end{array}$ \\
\hline 15 & $\begin{array}{l}\text { Western University } \\
\text { Libraries (Western) }\end{array}$ & https://www.lib.uwo.ca/ & $\begin{array}{l}\text { https://www.lib.uwo.ca/ } \\
\text { news/2020/ } \\
\text { covid19pandemic.html }\end{array}$ \\
\hline
\end{tabular}

Table 1: Canadian university research libraries with their homepage URLs, and COVID-19 update webpages

\begin{tabular}{|c|c|c|c|c|c|c|}
\hline \multicolumn{2}{|c|}{$\begin{array}{c}\text { Canadian } \\
\text { University } \\
\text { Research Libraries }\end{array}$} & Facebook & Twitter & YouTube & Instagram & Others \\
\hline 1 & Alberta & $x$ & $x$ & $x$ & $x$ & - \\
\hline 2 & British Columbia & $\mathrm{x}$ & $\mathrm{x}$ & - & - & - \\
\hline 3 & Calgary & $\mathrm{x}$ & $\mathrm{x}$ & $\mathrm{x}$ & - & - \\
\hline 4 & Dalhousie & $x$ & $x$ & $x$ & $x$ & Pinterest \\
\hline 5 & Laval & $x$ & - & - & - & - \\
\hline 6 & Manitoba & - & - & $x$ & - & - \\
\hline 7 & McGill & $\mathrm{x}$ & $x$ & $x$ & $\mathrm{x}$ & - \\
\hline 8 & McMaster & $x$ & $x$ & $x$ & $\mathrm{x}$ & Snapchat \\
\hline 9 & Montréal & $x$ & $x$ & $x$ & - & - \\
\hline 10 & Ottawa & $x$ & $x$ & - & - & - \\
\hline 11 & Queen's & $x$ & $x$ & $x$ & $x$ & - \\
\hline 12 & Saskatchewan & $x$ & $x$ & $x$ & $x$ & - \\
\hline 13 & Toronto & $x$ & $x$ & $x$ & $x$ & $\begin{array}{c}\text { Blogspot, } \\
\text { Pinterest, } \\
\text { Google } \\
\text { Plus }\end{array}$ \\
\hline 14 & Waterloo & $x$ & $x$ & $x$ & $x$ & - \\
\hline 15 & Western & - & $x$ & $x$ & - & - \\
\hline
\end{tabular}

Table 2: Canadian university research libraries' social media accounts (April 2020) 


\section{Findings \\ Reduction in access}

In our sample, 13 out of the 15 libraries, including their branch libraries, closed entirely until future notice following recommendations from their respective local public health offices to limit the spread of COVID-19. However, Alberta decided to keep their main library's first level open but with an access limit of a maximum of 15 users. Alberta staff frequently went around the library to disinfect and clean high touch surfaces including computer stations, door handles, and tables. On the other hand, Waterloo closed most of its branch libraries except the Pharmacy Resource Centre, which was physically accessible but with no library staff on-site. Importantly, we need to acknowledge here that university libraries are not fully autonomous in deciding when to close or stay open during the global health crisis. Library management teams have to discuss reduction in access during the COVID-19 pandemic with the top-level university administration.

\section{Reduction in services}

Closures also meant that all in-person services related to the physical collections, including the borrowing of books, course reserves, equipment, inter-library loans, and print document delivery, were not available to users during the early days of the COVID-19 pandemic. However, our data sets indicate that Dalhousie decided to continue loaning out their laptops to their students and professors. Alberta indicated that their 3D printer service was discontinued on their COVID-19 update webpage, while Western mentioned no access to graduate study carrels. Calgary, McMaster, Montréal, Ottawa, Saskatchewan, and Toronto specified that all scheduled in-person workshops and social events run by libraries were suspended. Many of those workshops were later being offered online. We found that inter-library loans and document delivery services changed to digital format delivery only. No physical item requested as an interlibrary loan would be processed at that time. Laval informed users that any document scanning requests needed to be in compliance with copyright. Manitoba further informed users that it would not be possible to return items scheduled to be returned to external libraries before the pandemic began.

On social media platforms, library staff in this study generated and shared information about their closure due to the COVID-19 outbreak. For example, British Columbia posted on Facebook on April 29, 2020 that "Due to the COVID-19 situation, UBC Library branches across the Vancouver and Okanagan campuses will remain closed until further notice. Electronic resources and librarian support for research, teaching and learning are available." Similarly, Montréal posted on Facebook on March 18 that, "Les bibliothèques de l'Université de Montréal sont fermées jusqu'à nouvel ordre. Toutefois, nous assurerons l'aide en ligne. Vous pouvez nous écrire par courriel ou clavarder avec nous du lundi au vendredi de $9 \mathrm{~h}$ à $17 \mathrm{~h}$ à partir de notre site web...Les ressources en ligne demeurent accessibles" [The Université de Montréal libraries are closed until further notice. However, we will provide help online. You can write us by email or chat with us Monday to Friday from 9 am to 5 pm from our website...Online resources remain available]. 


\section{Promoting the use of online resources}

Library staff included in this study promoted their virtual services, which were greatly in need and the only channel through which users could access collections during the early days of the COVID-19 pandemic. All relevant staff promoted access and usage of their e-books, e-journals, databases, and other online materials through the library online catalogues embedded in the library websites. In addition, while there was no access to print books and course reserve materials during the early days of the COVID-19 pandemic, many publishers made some of their e-text books and e-journals accessible for free, including items to which the libraries had not previously subscribed. British Columbia, Dalhousie, Laval, McGill, McMaster, Montréal, Ottawa, Waterloo, and Western universities promoted the latest open access items and other open educational resources as a supplement to the temporarily unavailable print materials to help students and professors getting through this unprecedented global health crisis. Moreover, Montréal, Laval, McGill, Waterloo, and Western universities advised their users that they would still continue to accept e-book purchase suggestions for research and teaching activities.

On social media platforms, library staff in this study generated and shared information about several publishers who had opened up free access to their content during the COVID-19 outbreak. For an example, McGill posted on Facebook on May 25, 2020:

Remember, we've compiled an ever-changing list of temporary open \& free resources to help support the \#McGill community with remote instruction \& learning. During this time, many publishers are offering some or all of their e-resources freely for a period of a few months. While not exhaustive, the Library will continue to add resources to this page as we find out about them.

Similarly, McMaster posted on Facebook on May 27, 2020 that "Many publishers have responded to the need to provide online resources by temporarily opening up access to content. Right here is where we highlight changes that are particularly relevant to McMaster."

McGill, McMaster, Montréal, Ottawa, Queen's, Saskatchewan, Toronto, and Waterloo universities clearly explained on their COVID-19 update webpages information about their university login, proxy settings, and Virtual Private Network (VPN) connections for off-campus access. McMaster instructed users that "Online resources can be accessed through the Library by logging in with your MAC ID when attempting to access an item...A VPN connection is not required," whereas McGill indicated that "Due to a projected increase in the usage of the McGill VPN during the campus closure, the VPN is temporarily unavailable as a method to access McGill Library's electronic resources. Please access e-resources via the Library catalogue or through the Databases A-Z which contain links using EZproxy."

In addition, the subject research guides (commonly referred to in Canada as "LibGuides") and the online tutorials related to information literacy and other research skills produced by librarians were strongly recommended on the COVID-19 update webpages of Alberta, British Columbia, Dalhousie, Manitoba, McMaster, Ottawa, Queen's, Saskatchewan, Toronto, and Waterloo university libraries. Especially promoted 
were the online tutorial videos of British Columbia, which cover a wide range of topics including planning research, finding resources, evaluating and citing sources, and publishing research.

\section{Transitioning to virtual services}

Moreover, in order to effectively answer user enquiries during the early days of the COVID-19 pandemic, all 15 university libraries in this study strongly promoted their virtual reference services which included online chat, email, and telephone. Montréal, Western, and Toronto university libraries communicated to their users that their subject librarians could still be directly reached by email to assist faculty in their teaching, online workshops, research support, the transition from face-to-face courses to online courses, copyright, and electronic document delivery and purchase. For graduate students, libraries could help regarding information management tools, systematic review procedures, institutional repository, bibliometrics, and research impact measures. Furthermore, Manitoba, McMaster, Queen's, Saskatchewan, and Waterloo libraries indicated that copyright enquiry services would be provided via email and telephone.

On social media platforms, library staff in this study generated and shared information about access and usage of their electronic collections and online services. To give an example, Toronto posted on Twitter on May 28, 2020, targeting instructors specifically, "Some great tips from the @chronicle relevant to \#UofT instructors teaching remotely while our physical libraries are closed. Don't hesitate to reach out to us for assistance with locating resources for your teaching or research." Waterloo posted on Facebook on May 11, 2020 about the extended hours of their chat service, saying "We've expanded our chat service hours this term to assist with your research needs. Chat service is happening Monday to Friday 9 a.m. to 9 p.m. and Saturday and Sunday noon to 9 p.m." Similarly, Western posted on Twitter on May 27, 2020 to promote their chat service, stating "Meet Sarah. Sarah likes to help. Sarah and our other experts on Chat are waiting for your questions. So the real question is... What are you waiting for?" In another example, the Dean of Dalhousie posted on the library's Facebook page on May 20, 2020 to the graduates of class 2020 explaining how the library supported students and professors during this time of the COVID-19 pandemic with the digital collections and online services with the following:

A Convocation Message from the Dalhousie Libraries. On behalf of the Dalhousie Libraries, I'm offering heart-felt congratulations to you all. We know the hard work and sacrifice it took for you to get to this day and we are very proud of you! This year ended on a particularly challenging note, but even through these unusual circumstances, it has been our honour and our pleasure to support your academic needs, most recently providing access to e-books, e-journals, LiveHelp reference support and assistance in Brightspace for students and professors, and before that with the full range of services in our beautiful library spaces...

\section{Change in borrowing regulations}

All 15 Canadian university research libraries used the same strategy to suspend fees associated with late returns for checked-out items during the COVID-19 lockdown. The library personnel in this study also automatically renewed the borrowed items with a new date with a possibility of setting another new date again in the future, if the 
lockdown continued longer. Alberta reset the new due date extension to May 31, 2020. Dalhousie moved the due date for items on loan to May 30, 2020. Manitoba extended the new date of loan maturity to August 22, 2020. McGill set the due date until midJune 2020. At Montréal, all loans were extended to May 7, 2020. Comparatively, the rest of library staff in this study did not indicate a firm due date. British Columbia, Calgary, Laval, McMaster, Ottawa, Queen's, Saskatchewan, Toronto, Waterloo, and Western advised users to renew materials online and recommended that they not come to campus to return books. The general message was that all items should be returned when the libraries officially reopened. In some cases, when users absolutely needed to return the checked-out items, they could be done by dropping the checked-out materials inside the book bins located outside of the library buildings.

On social media platforms, library personnel in this study generated and shared information about the late fee suspension during the early days of the COVID-19 pandemic. For example, Alberta posted on Twitter on May 8, 2020 that "DYK, ALL DUE DATES HAVE BEEN EXTENDED?!?!? As we navigate our system-wide \#COVID19 shutdown, all checked-out loans in our NEOS Consortium are NOW due on September 30, 2020. \#StayHome \#StaySafe." Additionally, Ottawa posted on Twitter on May 19, 2020 that "We know you've got a lot to deal with right now and we don't want to add to it: any books or materials you've borrowed from the Library will be auto-renewed to April 30th and any overdue fines will be suspended."

\section{Discussion}

The findings indicate that the top 15 Canadian university research libraries implemented a number of services and changes for coping with the public health crisis in the early days of the COVID-19 pandemic. These included:

- Closing physical libraries;

- Suspending all physical collection services and in-person events;

- Continuing to provide virtual reference services;

- Promoting access and usage of electronic collections;

- Suspending late fees and renewing checked-out items with a new due date; and

- Advising users to wait to return borrowed items.

Our data identified that all services and changes needed to be quickly implemented to limit the spread of COVID-19. This primarily included means to limit physical access to the libraries and their collections in accordance with public health guidelines. These actions listed above reflect the libraries' adjustment of procedures in response to restrictions and their transition to digital means of delivering their information services and serving their clientele. Consequently, this meant that all libraries in this study moved to operating as full-scale digital libraries, as students and faculty transitioned to teaching and learning via the internet for their classes. This created a new challenge for the libraries to make themselves visible as a facility supporting online learning and research, beyond just being a location to access and use e-journals and e-books. 
After the COVID-19 pandemic ends, how the libraries will operate with possibly reduced resources could be an issue. All of those in this study mostly receive funding through their universities from the government and some international student fees. Those revenues may drop. This means that libraries need to prepare to work with less. We might see the discontinuing of some electronic collections, or reducing the number of staff, or increases in the remaining workloads as hiring freezes may be implemented. There definitely will be new challenges and changes for all information organizations operating in the post COVID-19 era.

At the time of writing, many university libraries in Canada were preparing for a first phase reopening in summer 2020 by allowing users to access print materials using a curbside pickup model. In general, users would still have no access to the library building to browse the bookshelves. Users would have to place an order in advance and library staff would get the requested books and schedule a date and time for curbside pickup. For returns, the items would not be placed back on the bookshelves right away. They would need to be disinfected or isolated for a few days to ensure that any potential trace of the COVID-19 virus on the book surface was completely gone before the item would be made available for the next user.

In this first phase of the reopening of on-site services, libraries have to ensure the health and safety of the staff who will be involved in the curbside pickup plan. In addition, there is some discussion about how to safely allow all library staff to return to work inside the library building. One idea is to ask staff to come to their offices in different time slots to minimize personal contact as much as possible. Libraries might have to change the layout of shared open working spaces and some areas like the circulation counter would have to install protective plexiglass walls. Some library staff who could do their work online would be asked to continue working from home.

\section{Limitations}

This study has some limitations. We only focused on the top research-intensive universities in Canada. The strategies used among the small and medium sized universities and colleges were not explored. Therefore, there is a need of another study of those libraries because they too have been greatly affected by COVID-19. As they have smaller budgets compared to the large research university libraries, it is possible that their current budgets limit the scope of the online services and e-collections they could offer to their students and instructors and they might have to come up with other creative strategies which do not have a high cost to cope with the COVID-19 pandemic. This is an interesting research question that we think deserves to be further investigated. We also would like to recommend that other researchers look at the strategies used by information organizations in different countries and then compare the services and changes based on the countries' income levels (high, middle, and low). This kind of research will help us to better understand whether financial resources are likely to be the main determinant to indicate successful planning and management or if it is more about staff skills and the leadership of their management team that help them to get through the COVID-19 pandemic.

Another limitation of this paper is related to the data sources. We only used the data from public-facing websites related to COVID-19 updates and social media pages 
of the sample university libraries. This excludes internal communications regarding university library services such as emails sent to students and professors, internal communications, and other documents. Due to the limited access to obtain those documents and the urgency of this research the researchers did not have enough time to formally request those documents to be used in this paper.

\section{Conclusion}

This paper has provided an overview of the U15 libraries' approaches to their main webpages and social media service changes in response during the early days of the COVID-19 pandemic. By documenting service changes, it provides a benchmark for future studies on how research libraries might respond to a public health or other crises situations. Notably, all libraries in this study are operating as full-scale digital libraries. Their closures are only partial because library personnel are delivering basic services remotely. As we learn more about how the COVID-19 virus spreads and government reopening strategies change, we can expect these library services and changes to continue to evolve.

\section{Declaration of conflicting interests}

The authors declared no potential conflicts of interest with respect to the research, authorship, and/or publication of this article.

\section{Funding statement}

The authors received no financial support for the research, authorship, and/or publication of this article.

\section{About the Authors}

Channarong Intahchomphoo is a data research librarian at the University of Ottawa Library and a research fellow at the School of Electrical Engineering and Computer Science, University of Ottawa. Email: cintahch@uottawa.ca.

Michelle Brown is the head of Learning and Student Success at the University of Ottawa Library. Email: michelle.brown@uottawa.ca.

\section{References}

Ayris, Paul. 2012. "Developing European Library Services in Changing Times." LIBER Quarterly 21 (3-4): 331-346. http://doi.org/10.18352/lq.8029.

Beetseh, Kwaghga, Samuel Dzever Tion, and Victoria M. Terwase. 2018.

"Herdsmen/Farmers crises in Nigeria: The Role of Librarians in Resolving Crises." Library Philosophy and Practice 1. https://digitalcommons.unl.edu/libphilprac/1787.

Braun, Virginia, and Victoria Clarke. 2006. "Using Thematic Analysis in Psychology." 
Qualitative Research in Psychology 3 (2): 77-101.

Fitchett, Taylor, James Hambleton, Penny Hazelton, and Anne Klinefelter. 2011. "Law Library Budgets in Hard Times." Law Library Journal 103: 91-111. https://papers.ssrn.com/sol3/papers.cfm?abstract_id=1965643.

Government of Canada. "Coronavirus Disease (COVID-19): Outbreak Update." Accessed June 3, 2020. http://www.canada.ca/en/public-health/services/diseases/2019novel-coronavirus-infection. html?topic=tilelink.

Group of Canadian Research Universities. n.d. "U15." Accessed June 3, 2020. http://www.u15.ca.

Kanyengo, Christine Wamunyima. 2010. "Information and Communication: A Library's Local Response to HIV/AIDS in Zambia." Health Information \& Libraries Journal 27 (1): 57-65. https://doi.org/10.1111/j.1471-1842.2009.00855.x.

Pascarelli, Anne M. 1990. "Coping Strategies for Libraries Facing the Serials Pricing Crisis." Serials Review 16 (1): 75-80. https://doi.org/10.1016/00987913(90)90045-Z. 